\title{
Needles in a haystack: finding recurrent genomic changes in breast cancer
}

\author{
Justin Cidado, Julia A Beaver and Ben Ho Park*
}

\begin{abstract}
Significant advances over the past decade have enabled scientists to obtain increasingly detailed molecular profiles of breast cancer. The recent analysis by The Cancer Genome Atlas published in the September 2012 issue of Nature is the most comprehensive description of breast cancer 'omics' to date. This study is impressive in its scope and scale, with the findings reconfirming the heterogeneity of breast cancer and highlighting the future challenges in translating these findings for clinical benefit.
\end{abstract}

\section{Background}

Breast cancers are a heterogeneous group of tumors that were originally classified by their clinicopathological features. Improvements in molecular techniques, specifically in gene expression analysis, allowed for the grouping of breast cancers into five subtypes (luminal A, luminal B, basal-like, HER2-enriched (HER2E), and normal-like) over a decade ago [1,2]. Typically, luminal subtypes are associated with the expression of estrogen receptor (ER) and progesterone receptor, while HER2E subtypes usually lack hormone receptor expression but have amplification and/or over-expression of HER2. Basal-like tumors are commonly described as triple-negative breast cancers (TNBCs) lacking in expression of hormone receptors and HER2.

While receptor subtypes are associated with different prognostic and therapeutic implications, the full clinical consequences of these molecular subtypes have not been established. In 2006 and 2007, two studies published in Science detailed the complexity of the breast cancer mutation spectrum and highlighted the major difficulties this diversity raises in designing therapies [3,4]. In June 2012, five studies were published in Nature examining

*Correspondence: bpark2@jhmi.edu

The Sidney Kimmel Comprehensive Cancer Center at Johns Hopkins, Department of Oncology, 1650 Orleans Street, CRBI, Room 151, Baltimore, MD 21287, USA hundreds of primary breast tumors by integrating various profiling techniques [5-9]. These recent papers demonstrated a vast array of clonal frequencies and genetic diversity among breast cancers, highlighting that breast cancer is truly many different diseases.

\section{A comprehensive look at a complex molecular landscape}

The Cancer Genome Atlas (TCGA) is a collective effort tasked with providing a comprehensive genomic analysis for 20 cancers, including breast cancer. In this latest study, TCGA analyzed 825 primary breast tumors with matched germline samples using six different platforms (whole exome sequencing, messenger RNA array, genomic DNA copy number array, DNA methylation array, microRNA sequencing and reverse-phase protein array) [10]. The sequencing and array data corroborated the mutation and gene expression patterns documented in previous studies. For instance, compared to the noted low frequency of mutation for numerous genes across all breast cancers, TP53 (37\%), PIK3CA (36\%), and GATA3 (11\%) were the only genes found to be mutated at a level greater than $10 \%$ overall. In addition, when grouped according to gene expression subtype, the mutations not only tracked well with expected frequency but also with the type of mutation. Notably, basal-like tumors harbored nonsense TP53 mutations while luminal tumors harbored mostly missense mutations. In addition to identifying nearly all genes previously implicated in breast cancer, the authors also discovered a handful of novel mutated genes.

TCGA also parsed out individual, overarching features associated with each of the four subtypes: luminal A, luminal B, HER2E, and basal-like. Despite having a relatively low mutation rate, luminal/ER+ tumors were found to have the most diverse mutation spectrum and heterogeneity. Conversely, basal-like and HER2E tumors had a very high rate of mutation in only a few select genes, such as TP53. The data also showed that clinically defined TNBCs and HER2+ cancers did not fall exclusively within their classically associated subtypes, basallike and HER2E, respectively. In fact, only $50 \%$ of clinically defined HER2 + cancers were classified as 
HER2E while the other half tracked well with ER+ status and other luminal subtype features. As for TNBCs, 25\% of tumors comprised the three other mRNA subtypes besides the basal-like group. Interestingly, through further analysis of the basal-like subset of tumors, TCGA noticed strikingly similar characteristics and mutations as in their previous studies with serous ovarian cancers. Both tumor types featured widespread genomic instability, MYC amplification, and loss of BRCA1, TP53, and RB1, leading to the authors' conclusion that patients with basal-like tumors may benefit from poly ADP-ribose polymerase (PARP) inhibitors or platinum-based therapies.

\section{Viewpoint}

While multiple groups have attempted to create consensus mutation spectrums and molecular landscapes for primary breast cancers, TCGA was able to draw from a large database across multiple platforms and provide the most comprehensive portrait of human breast tumors thus far. All six recent profiling analyses detailed the same intricate and heterogeneous nature of breast cancers and emphasized the difficulties this causes with respect to the development of effective therapies. However, the sobering truth is that common targets are the exception in breast cancer, and if there were any remaining doubts, TCGA has put them to rest. How to move this information forward for clinical benefit becomes the challenge for the next decade. Although the technical merits and scale of this study cannot be discredited, in reality no new clinical benefit can yet be derived, as even the idea to use PARP inhibitors or platinum agents to treat TNBC has already been an intense area of clinical research. In addition, future studies will need to address issues with intratumor heterogeneity and clonal evolution. It is hoped that the classification of breast cancers along with further technologic advances can lead to the development of more rational therapeutics, so that ultimately the vision of individualized therapy for breast cancer becomes a reality.

\section{Abbreviations}

ER, estrogen receptor; HER2E, HER2-enriched; PARP, poly ADP-ribose polymerase; TCGA, The Cancer Genome Atlas; TNBC, triple-negative breast cancer.

\section{Competing interests}

BHP is a consultant for GlaxoSmithKline and serves on the Scientific Advisory Board of Horizon Discovery, Ltd.

Published: 19 February 2013
References

1. Perou CM, Sørlie T, Eisen MB, van de Rijn M, Jeffrey SS, Rees CA, Pollack JR, Ross DT, Johnsen H, Akslen LA, Fluge O, Pergamenschikov A, Williams C, Zhu SX, Lønning PE, Børresen-Dale AL, Brown PO, Botstein D: Molecular portraits of human breast tumours. Nature 2000, 406:747-752.

2. Sørlie T, Perou CM, Tibshirani R, Aas T, Geisler S, Johnsen H, Hastie T, Eisen MB, van de Rijn M, Jeffrey SS, Thorsen T, Quist H, Matese JC, Brown PO, Botstein D, Lønning PE, Børresen-Dale AL: Gene expression patterns of breast carcinomas distinguish tumor subclasses with clinical implications. Proc Natl Acad SciU S A 2001, 98:10869-10874.

3. Sjöblom T, Jones S, Wood LD, Parsons DW, Lin J, Barber TD, Mandelker D, Leary RJ, Ptak J, Silliman N, Szabo S, Buckhaults P, Farrell C, Meeh P, Markowitz SD, Willis J, Dawson D, Willson JK, Gazdar AF, Hartigan J, Wu L, Liu C,

Parmigiani G, Park BH, Bachman KE, Papadopoulos N, Vogelstein B, Kinzler KW, Velculescu VE: The consensus coding sequences of human breast and colorectal cancers. Science 2006, 314:268-274.

4. Wood LD, Parsons DW, Jones S, Lin J, Sjöblom T, Leary RJ, Shen D, Boca SM, Barber T, Ptak J, Silliman N, Szabo S, Dezso Z, Ustyanksky V, Nikolskaya T, Nikolsky Y, Karchin R, Wilson PA, Kaminker JS, Zhang Z, Croshaw R, Willis J, Dawson D, Shipitsin M, Willson JK, Sukumar S, Polyak K, Park BH, Pethiyagoda $\mathrm{CL}$, Pant PV, et al:: The genomic landscapes of human breast and colorectal cancers. Science 2007, 318:1108-1113.

5. Curtis C, Shah SP, Chin SF, Turashvili G, Rueda OM, Dunning MJ, Speed D, Lynch AG, Samarajiwa S, Yuan Y, Gräf S, Ha G, Haffari G, Bashashati A, Russell R, McKinney S; METABRIC Group, Langerød A, Green A, Provenzano E, Wishart G, Pinder S, Watson P, Markowetz F, Murphy L, Ellis I, Purushotham A, BørresenDale AL, Brenton JD, Tavaré S, Caldas C, Aparicio S: The genomic and transcriptomic architecture of 2,000 breast tumours reveals novel subgroups. Nature 2012, 486:346-352.

6. Stephens PJ, Tarpey PS, Davies H, Van Loo P, Greenman C, Wedge DC, NikZainal S, Martin S, Varela I, Bignell GR, Yates LR, Papaemmanuil E, Beare D, Butler A, Cheverton A, Gamble J, Hinton J, Jia M, Jayakumar A, Jones D, Latimer C, Lau KW, McLaren S, McBride DJ, Menzies A, Mudie L, Raine K, Rad R, Chapman MS, Teague J, et al.: The landscape of cancer genes and mutational processes in breast cancer. Nature 2012, 486:400-404.

7. Shah SP, Roth A, Goya R, Oloumi A, Ha G, Zhao Y, Turashvili G, Ding J, Tse K, Haffari G, Bashashati A, Prentice LM, Khattra J, Burleigh A, Yap D, Bernard V, McPherson A, Shumansky K, Crisan A, Giuliany R, Heravi-Moussavi A, Rosner J, Lai D, Birol I, Varhol R, Tam A, Dhalla N, Zeng T, Ma K, Chan SK, et al.: The clonal and mutational evolution spectrum of primary triple-negative breast cancers. Nature 2012, 486:395-399.

8. Ellis MJ, Ding L, Shen D, Luo J, Suman VJ, Wallis JW, Van Tine BA, Hoog J, Goiffon RJ, Goldstein TC, Ng S, Lin L, Crowder R, Snider J, Ballman K, Weber J, Chen K, Koboldt DC, Kandoth C, Schierding WS, McMichael JF, Miller CA, Lu C, Harris CC, McLellan MD, Wendl MC, DeSchryver K, Allred DC, Esserman L, Unzeitig G, et al:: Whole-genome analysis informs breast cancer response to aromatase inhibition. Nature 2012, 486:353-360.

9. Banerji S, Cibulskis K, Rangel-Escareno C, Brown KK, Carter SL, Frederick AM, Lawrence MS, Sivachenko AY, Sougnez C, Zou L, Cortes ML, Fernandez-Lopez JC, Peng S, Ardlie KG, Auclair D, Bautista-Piña V, Duke F, Francis J, Jung J, Maffuz-Aziz A, Onofrio RC, Parkin M, Pho NH, Quintanar-Jurado V, Ramos AH, Rebollar-Vega R, Rodriguez-Cuevas S, Romero-Cordoba SL, Schumacher SE, Stransky N, et al: Sequence analysis of mutations and translocations across breast cancer subtypes. Nature 2012, 486:405-409.

10. Cancer Genome Atlas Network: Comprehensive molecular portraits of human breast tumours. Nature 2012, 490:61-70.

doi:10.1186/bcr3364

Cite this article as: Cidado J, et al:: Needles in a haystack: finding recurrent genomic changes in breast cancer. Breast Cancer Research 2013, 15:304. 